\title{
PERBEDAAN TEKNIK PENANAMAN TERHADAP HASIL JUMLAH KOLONI BAKTERI Escherichia coli PADA SUHU INKUBASI $36^{\circ} \mathrm{C}$
}

\author{
Vincentia Ade Rizky, Sa'adah Siregar, Visensius Krisdianilo, Jhon Patar Sinurat \\ Institut Kesehatan Medistra Lubuk Pakam \\ Jurusan Teknologi Laboratorium Medik \\ Jl. Sudirman, No. 38, Lubuk Pakam, Deli Serdang, Sumatera Utara, 20512 \\ e-mail : vincentiarizky@gmail.com

\section{DOI: https://doi.org/10.35451/jfm.v1i2.173}

\begin{abstract}
Escherichia coli bacteria are gram-negative bacteria in form of single or paired cells it is included Enterobacteriaceae family and intestinal normal flora. Laboratory tests conducted for the calculation of the number of germs can be done using cultivation techniques using a loop and micropipet. The aim of this research is to know the difference of number of bacteria bacteria on calibrated loop and micropipet to colony of Escherichia coli bacteria. This research is an analytical observation study with cross sectional design. The hypothesis was tested using independent $t$ test with 95\% confidence level. The results showed the average number colonies of Escherichia coli bacteria growing on PCA media using calibrated loop technique was 138,25 $\mathrm{CFU} / \mathrm{mL}$ where as the average number of colonies of Escherichia coli bacteria grown on PCA media using micropipet technique was 104,56 CFU/mL, and significant value of $p=0,001$. Furthemore, the result of data analysis showed that there were no any differences in the number of colonies of Escherichia coli bacteria in planting using calibrated loop technique and micropipet at incubation temperature of $36^{\circ} \mathrm{C}$.
\end{abstract}

Keywords: E. coli, incubation temperature of $36^{\circ} \mathrm{C}$, micropipet

\section{PENDAHULUAN}

Bakteri Escherichia coli merupakan flora normal organ intestinal berbentuk batang gram negatif dari keluarga Enterobacteriaceae. Bakteri ini dapat menjadi patogen bila mencapai jaringan diluar jaringan intestinal (Hera, 2004).

Escherichia coli merupakan mikroorganisme tersering penyebab infeksi saluran kemih. Infeksi saluran kemih (ISK) merupakan suatu penyakit dimana jumlah bakteriuria terdapat $\geq 10^{8}$ bakteri per liter (ekivalen dengan $\geq 10^{5}$ bakteri/mL) sampel urine tengah (midstream) segar (Elliott et al., 2013).

Diagnosis pasti ISK (Gold standard) dapat ditegakkan dengan kultur urine yaitu dengan cara menghitung jumlah koloni bakteri pada media kultur dengan metode CFU/Colony Forming Unit (Davey, 2005).

Tahap analitik merupakan salah satu tahapan yang sangat penting untuk menegakkan diagnosa klinis bakteri Escherichia coli. Tahap ini harus dhindari dari kesalahan agar pemantapan mutu laboratorium mikrobiologi dapat ditegakkan. Salah satu yang harus diperhatikan dalam tahap analitik adalah suhu inkubasi dan alat penanaman.

Bakteri Escherichia coli dapat tumbuh pada suhu $10-40^{\circ} \mathrm{C}$ dengan suhu optimum pertumbuhan bakteri Escherichia coli $35-37^{\circ} \mathrm{C}$ (Radji, 2010). Pada penelitian ini suhu yang digunakan adalah suhu optimum pertengahan yaitu suhu $36^{\circ} \mathrm{C}$. 
Menurut WHO (2003) tentang Basic

Laboratory Procedures In

Clinical Bacteriology menyatakan bahwa teknik biakan untuk kultur urine menggunakan teknik sengkelit dan teknik carik celup kertas saring. Menurut Sonnenwirth et al., (1980) menyatakan bahwa teknik biakan untuk kultur urine menggunakan teknik sengkelit dan mikropipet.

\section{METODE}

Jenis penelitian yang digunakan adalah observasi analitik dengan rancangan penelitian cross sectional. Sampel yang digunakan pada penelitian ini adalah Escherichia coli ATCC 25922. Data yang didapatkan dianalisa menggunakan SPSS dengan uji Independent t test.

\section{Hasil dan Pembahasan}

Hasil jumlah koloni bakteri yang tumbuh pada suhu $36^{\circ} \mathrm{C}$ menggunakan sengkelit dan mikropipet (tabel 1).

Tabel 1. Hasil Jumlah Koloni

\begin{tabular}{|c|c|c|}
\hline No & $\begin{array}{c}\text { Teknik } \\
\text { Sengkelit }\end{array}$ & $\begin{array}{c}\text { Teknik } \\
\text { Mikropipet }\end{array}$ \\
\hline 1 & 140 & 119 \\
\hline 2 & 133 & 103 \\
\hline 3 & 156 & 121 \\
\hline 4 & 135 & 71 \\
\hline 5 & 126 & 115 \\
\hline 6 & 137 & 91 \\
\hline 7 & 144 & 110 \\
\hline 8 & 130 & 75 \\
\hline 9 & 136 & 89 \\
\hline 10 & 138 & 124 \\
\hline 11 & 139 & 116 \\
\hline 12 & 132 & 92 \\
\hline 13 & 140 & 117 \\
\hline 14 & 143 & 113 \\
\hline 15 & 142 & 105 \\
\hline 16 & 141 & 112 \\
\hline Jumlah & 2212 & 1673 \\
\hline
\end{tabular}

\section{Rata-rata $\quad 138.25$ \\ 104.56 \\ Pada penelitian yang telah} dilakukan dan dianalisa berdasarkan hasil uji independent $\mathrm{t}$ test didapatkan nilai signifikan $=0,001$ lebih kecil dari nilai alpa $=0,05$, artinya terdapat perbedaan jumlah koloni bakteri Escherichia coli pada media Plate Count Agar menggunakan teknik sengkelit dan teknik mikropipet.

Adanya perbedaan jumlah koloni pada kedua teknik dapat dilihat dari pertumbuhan koloni pada media. Pertumbuhan koloni pada media yang ditanam menggunakan teknik sengkelit hampir tersebar merata, hal ini dikarenakan teknik yang digunakan pada saat menggores permukaan media membentuk satu garis lurus kemudian disebarkan secara zig-zag menggunakan sengkelit. Sedangkan pertumbuhan koloni yang ditanam menggunakan teknik mikropipet bertumpuk, hal ini dikarenakan teknik yang digunakan untuk menyebarkan cairan menggunakan spreder atau batang gelas bengkok. Hal ini pula didukung oleh penelitian yang telah dilakukan Kadri (2015).

\section{Kesimpulan}

Berdasarkan hasil penelitian bakteri Escherichia coli pada penanaman menggunakan teknik sengkelit dan mikropipet yang ditunjukkan dengan pertumbuhan koloni bakteri pada media dengan jumlah koloni yaitu rata-rata jumlah koloni menggunakan teknik sengkelit adalah 138,25 CFU/mL, sedangkan teknik mikropipet adalah 104,56 CFU/mL. Sehingga, dapat disimpulkan terdapat perbedaan jumlah koloni bakteri Escherichia coli pada penanaman menggunakan teknik sengkelit dan teknik mikropipet.

Adapun saran dari penelitian ini adalah perlu dilakukan penelitian lebih lanjut untuk jumlah koloni bakteri yang ditanam menggunakan 
teknik sengkelit pada suhu inkubasi $35^{\circ} \mathrm{C}, 36^{\circ} \mathrm{C}$, dan $37^{\circ} \mathrm{C}$.

\section{DAFTAR PUSTAKA}

Davey P (2005). At a Glance Medicine. Jakarta : Erlangga

Elliott T, Worthington T, Osman H, Gill M (2013). Mikrobiologi Kedokteran \& Infeksi Edisi 4. Jakarta : EGC

Hera, Noviana (2004). Pola kepekaan antibiotik Eschericia coli yang diisolasi dari berbagai spesimen klinis. Jakarta : Universitas Katolik Atma Jaya Jakarta

Kadri AN, Gelgel KTP, Suarjana IGK (2015). Perbedaan cara Penyebaran Suspensi Terhadap Jumlah Bakteri Pada Media Eosin Methylene Blue Agar. Jurnal Indonesia Medicus Veterinus, 4 (3) : 205 212

Radji M (2010). Buku Ajar Mikrobiologi Panduan

Mahasiswa Farmasi \&

Kedokteran. Jakarta : EGC

Sonnenwirth AC, Jarett L (1980). Gradwohl's Clinical Laboratory Method and Diagnosis, Vol. II. St Louis : CV Mosby Company

World Health Organization (2003). Basic Laboratory Procedures In Clinical Bacteriology, 2nd Ed. Switzerland, Geneva. 